\title{
Addition of insulin glargine or NPH insulin to metformin monotherapy in poorly controlled type 2 diabetic patients decreases IGF-I bioactivity similarly
}

\author{
A. J. Varewijck • J. A. M. J. L. Janssen • M. Vähätalo • \\ L. J. Hofland • S. W. J. Lamberts • H. Yki-Järvinen
}

Received: 20 October 2011 / Accepted: 5 December 2011 / Published online: 10 January 2012

(C) The Author(s) 2012. This article is published with open access at Springerlink.com

\begin{abstract}
Aims/hypothesis The aim of this study was to compare IGFI bioactivity 36 weeks after the addition of insulin glargine (A21Gly,B31Arg,B32Arg human insulin) or NPH insulin to metformin therapy in type 2 diabetic patients who had poor glucose control under metformin monotherapy.

Methods In the Lantus plus Metformin (LANMET) study, 110 poorly controlled insulin-naive type 2 diabetic patients were randomised to receive metformin with either insulin glargine (G+MET) or NPH insulin (NPH+MET). In the present study, IGF-I bioactivity was measured, retrospectively, in 104 out of the 110 initially included LANMET participants before and after 36 weeks of insulin therapy. IGF-I bioactivity was measured using an IGF-I kinase receptor activation assay.

Results After 36 weeks of insulin therapy, insulin doses were comparable between the G+MET $(68 \pm 5.7 \mathrm{U} /$ day $)$ and NPH+MET $(71 \pm 6.2 \mathrm{U} /$ day) groups $(p=0.68)$. Before insulin therapy, circulating IGF-I bioactivity was similar between the G+MET (134 $\pm 9 \mathrm{pmol} / \mathrm{l})$ and NPH+MET (135 $\pm 10 \mathrm{pmol} / \mathrm{l})$ groups $(p=0.83)$. After 36 weeks, IGF-I bioactivity had decreased significantly $(p=0.001)$ and did not differ between the G+MET (116 \pm 9 pmol/l) and NPH+MET (117 \pm
\end{abstract}

A. J. Varewijck · J. A. M. J. L. Janssen $(\triangle) \cdot$ L. J. Hofland •

S. W. J. Lamberts

Department of Internal Medicine, Division of Endocrinology,

Erasmus MC,

's-Gravendijkwal 230,

3015 CE Rotterdam, the Netherlands

e-mail: j.a.m.j.l.janssen@erasmusmc.nl

M. Vähätalo

City of Turku Health Centre,

Turku, Finland

H. Yki-Järvinen

Department of Medicine, University of Helsinki,

Helsinki, Finland
$10 \mathrm{pmol} / \mathrm{l})$ groups $(p=0.91)$. At baseline and after insulin therapy, total IGF-I concentrations were comparable in both groups (baseline: G+MET $13.3 \pm 1.0$ vs NPH+MET $13.3 \pm$ $1.0 \mathrm{nmol} / 1, p=0.97$; and 36 weeks: $13.4 \pm 1.0$ vs $13.1 \pm$ $0.9 \mathrm{nmol} / 1, p=0.71)$. Total IGF-I concentration did not change during insulin therapy $(13.3 \pm 0.7$ vs $13.3 \pm 0.7 \mathrm{nmol} / \mathrm{l}$, baseline vs 36 weeks, $p=0.86$ ).

Conclusions/interpretation Addition of insulin glargine or $\mathrm{NPH}$ insulin to metformin monotherapy in poorly controlled type 2 diabetic patients decreases serum IGF-I bioactivity in a similar manner.

Keywords IGF-I bioactivity - Insulin glargine · Insulin therapy · NPH insulin · Total IGF-I · Type 2 diabetes

$\begin{array}{ll}\text { Abbreviations } \\ \text { AMPK } & \text { AMP-activated protein kinase } \\ \text { G+MET } & \text { Insulin glargine and metformin } \\ \text { HEK } & \text { Human embryonal kidney } \\ \text { IGFBP } & \text { IGF binding proteins } \\ \text { IGF-IR } & \text { IGF-I receptor } \\ \text { IR } & \text { Insulin receptor } \\ \text { KIRA } & \text { Kinase receptor activation } \\ \text { LANMET } & \text { Lantus+Metformin } \\ \text { NPH+MET } & \text { NPH insulin and metformin }\end{array}$

Introduction

In 2009 four observational studies were published of which three suggested that the use of insulin glargine (A21Gly, B31Arg,B32Arg human insulin) was associated with an increased risk of cancer [1-4]. The US Food and Drug Administration (FDA) reviewed these four studies and concluded that 'the evidence presented was inconclusive, due to 
limitations in how the studies were designed, carried out and in the data available for analysis' [5].

Nevertheless these findings have raised concerns as to whether or not insulin glargine promotes cell proliferation and growth of neoplasms. In vitro, at high concentrations, insulin glargine has been found to be more potent than human insulin in stimulating the IGF-I receptor (IGF-IR) [6-10]. By using an in-house IGF-I kinase receptor activation (KIRA) assay, we recently confirmed that insulin glargine, at high concentrations, is more potent than either human insulin or insulin detemir in activating the human IGF-IR in vitro [7]. This assay uses human embryonic kidney (HEK) cells overexpressing the human IGF-IR to quantify IGF-IR phosphorylation in response to stimulation by specific ligands or human serum $[11,12]$. The dose-dependent effect of insulin glargine supports the finding of a potential link between higher doses of insulin glargine and incidence of cancer reported in a case control study by Mannucci et al [13].

Previously, Mayer et al have published a pilot study in which serum from type 1 diabetic patients treated with insulin glargine had a greater proliferative effect on MCF-7 breast cancer cells than serum containing human insulin [14]. There are, as yet, no studies comparing IGF-I bioactivity in type 2 diabetic patients during treatment with insulin glargine or NPH insulin. However, such studies would help to clarify whether insulin-mediated differences in IGF-IR activation in vitro translate into differences in IGF-I bioactivity in vivo.

In the Lantus+Metformin (LANMET) study, the efficacy and safety of bedtime insulin glargine was compared with $\mathrm{NPH}$ insulin in poorly controlled insulin-naive type 2 diabetic patients treated with metformin [15].

In the present study, we examined whether the addition of insulin glargine or NPH insulin to metformin monotherapy in poorly controlled type 2 diabetic patients induced changes in circulating IGF-I bioactivity, as measured by the IGF-I KIRA assay, and whether this response differed between the two insulins.

\section{Methods}

Study design and study population

The LANMET study was a multicentre, open, randomised, parallel-group study [15]. Briefly, in the LANMET study the efficacy and safety of bedtime insulin glargine and metformin $(\mathrm{G}+\mathrm{MET})$ was compared with NPH insulin and metformin $(\mathrm{NPH}+\mathrm{MET})$ treatment in insulin-naive poorly controlled type 2 diabetic patients $\left(\mathrm{HbA}_{1 \mathrm{c}} 8.0 \%\right.$ [64 $\left.\mathrm{mmol} / \mathrm{mol}\right]$ or higher). The study consisted of a 4 week run-in phase and a 36 week treatment phase. It was performed at six sites in Finland and one in the UK. The study was performed in accordance with the Declaration of Helsinki and good clinical practice, as described by Note for Guidance CPMP/ICH/135/ 95. Approval by institutional ethics committees was obtained for each participating site. All patients provided written informed consent before entry into the study.

In the present study, IGF-I bioactivity was measured, retrospectively, in participants of the LANMET study. All LANMET participants were included from whom extra serum samples had been collected as part of the original protocol (104 out of 110 LANMET participants, 95\% of the total number). In addition, 41 serum samples from nondiabetic participants (mostly spouses) were collected at the time of the baseline visit. The latter samples were analysed to compare IGF-I bioactivity and total IGF-I between type 2 diabetic patients and non-diabetic participants.

Since, previously, a dose-dependent increase in cancer risk was observed for treatment with insulin glargine compared with human insulin [1, 13], and differences between insulin analogues and human insulin in IGF-IR activation in vitro have only been reported at relatively high concentrations [6-10], we also performed a sub-analysis in 40 patients, who were treated with a mean daily insulin dose above $70 \mathrm{U} /$ day (20 patients in each treatment group).

\section{Materials and assays}

Serum IGF-I bioactivity and total serum IGF-I were measured in fasting blood samples before and after 36 weeks of insulin treatment from type 2 diabetic patients and from non-diabetic subjects (mostly spouses).

IGF-I KIRA bioassay The IGF-IR KIRA assay has been previously described $[11,12]$. Briefly, autophosphorylation of tyrosine residues located within the intracellular kinase domain of the IGF-IR is the first step in the intracellular signalling cascade. The IGF-IR KIRA assay uses a HEK cell line that is stably transfected with the human IGF-IR gene (HEK IGF-IR) and quantifies phosphorylation of tyrosine residues of the transfected IGF-IR to assess IGF-I bioactivity. After $48 \mathrm{~h}$ of culture, HEK IGF-IR cells were stimulated for $15 \mathrm{~min}$ at $37^{\circ} \mathrm{C}$ with recombinant IGF-I standards (Austral Biologicals, San Ramon, CA, USA), insulin glargine (Lantus; sanofi-aventis, Frankfurt am Main, Germany) and NPH insulin (Insulatard; Novo Nordisk, Bagsvaerd, Denmark). Equimolar concentrations of IGF-I, insulin glargine and NPH insulin were tested in a range of 100-100,000 pmol/1. Standards were diluted in Krebs-Ringer bicarbonate buffer adjusted to $\mathrm{pH} 7.4$ by $\mathrm{CO}_{2}$ and supplemented with $0.1 \%$ human serum albumin (Octalbine; Octopharma, Lachen, Switzerland). After stimulation, cells were lysed. Crude lysates were transferred to a sandwich assay. Wells were coated with a monoclonal antibody (MAD-1) directed against the IGF-IR (Novozymes-Gropep, Adelaide, Australia) that was used as capture antibody at a concentration of $5.0 \mu \mathrm{g} / \mathrm{ml}$. A 
biotinylated anti-phosphotyrosine monoclonal antibody (BAM 1676) (R\&D Systems Europe, Abingdon, UK) was used at a concentration of $0.2 \mu \mathrm{g} / \mathrm{ml}$ together with streptavidin labelled europium (DELFIA Eu-N1; PerkinElmer Life Sciences, Groningen, the Netherlands) at a concentration of $50 \mathrm{pmol} / \mathrm{l}$ as detection antibody. Contents were read in a time-resolved fluorimeter (Victor2 multilabel counter; PerkinElmer Life Sciences). Assays were performed in 48 well plates (Corning; Corning, NY, USA).

For measurements of serum IGF-I bioactivity, an IGF-I standard, two internal control samples and two study control samples were included on each culture plate. Serum samples were diluted 1:10. All measurements were carried out in duplicate. The intra-assay $\mathrm{CV}$ was $5.6 \%$. The inter-assay CVs were, respectively, $6.8 \%$ and $12.6 \%$ for the two internal control samples.

Statistical analysis

Baseline characteristics are shown as means (or geometric means) \pm SE. The Kolmogorov-Smirnov test was used to test normality of variables (data were considered to be normally distributed when $p>0.05$ ). For data that did not meet the criteria for normality, logarithmic transformations were applied. Pearson's correlation coefficients were calculated to assess the associations between variables. Pearson's correlation coefficients for IGF-I were calculated after adjustment for age. A univariate general linear model was used to test differences in continuous variables between the insulin treatment groups and non-diabetic participants; differences for total IGF-I and IGF-I bioactivity were calculated after adjustment for age and sex. Differences in categorical variables were tested by using the $\chi^{2}$ test. A paired $t$ test was used to test differences before and after starting insulin treatment. A $p$ value of 0.05 or less was considered statistically significant. Data were analysed using SPSS 17 for Windows (SPSS, Chicago, IL, USA).

\section{Results}

In vitro measurements

\section{Effects of insulin glargine and NPH insulin on IGF-IR activation}

Figure 1 shows that insulin glargine and NPH insulin were equally effective in activating the IGF-IR at 100 and $1,000 \mathrm{pmol} / 1$ ( $p=0.26$ and $p=0.34$, respectively). At 10,000 and $100,000 \mathrm{pmol} / \mathrm{l}$, insulin glargine was more potent than NPH insulin ( $p=0.02$ and $p=0.04$, respectively) (Fig. 1). Human recombinant IGF-I was more potent than human insulin and insulin glargine over the whole range tested (Fig. 1).

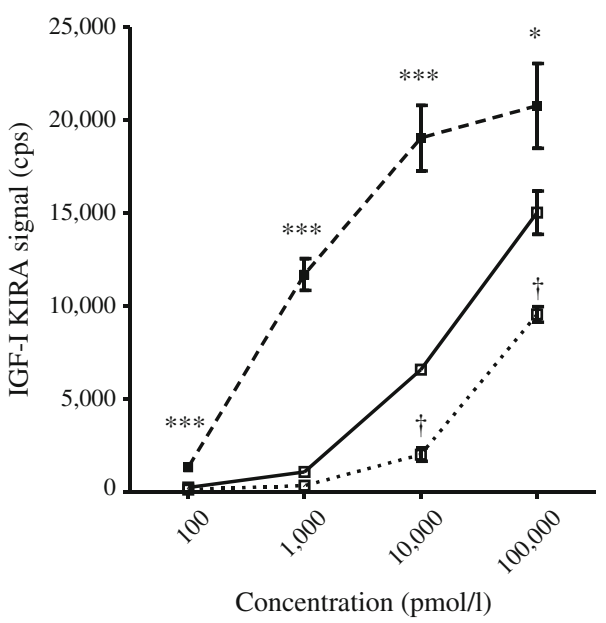

Fig. 1 Activation of the IGF-IR: comparing human IGF-I (dashed line, black squares), insulin glargine (solid line, white squares) and NPH insulin (dotted line, white squares). Dose-response profiles ranged from 100 to $100,000 \mathrm{pmol} / \mathrm{l}$. Points represent the mean value (+SEM) of three independent experiments. ${ }^{*} p<0.05$ for human IGF-I vs insulin glargine and NPH insulin; $* * * p<0.001$ for human IGF-I vs insulin glargine and NPH insulin; ${ }^{\dagger} p<0.05$ for insulin glargine vs NPH insulin

In vivo measurements

\section{Baseline characteristics}

Baseline characteristics of the two patient groups did not significantly differ from each other (Table 1). The nondiabetic participants (matched with respect to age and sex) were leaner and metabolically healthier compared with the type 2 diabetic participants (Table 1 ).

\section{Glycaemic control and insulin doses}

Mean $\mathrm{HbA}_{1 \mathrm{c}}$ concentrations were comparable in the $\mathrm{G}+\mathrm{MET}$ and NPH+MET groups before insulin therapy $(9.0 \pm 0.1 \%[75 \pm$ $1.1 \mathrm{mmol} / \mathrm{mol}]$ vs $9.2 \pm 0.2 \%[77 \pm 2.2 \mathrm{mmol} / \mathrm{mol}], p=0.33$ ) and decreased similarly in both groups after insulin therapy $(7.0 \pm 0.1 \%[53 \pm 1.1 \mathrm{mmol} / \mathrm{mol}]$ vs $7.1 \pm 0.1 \%$ $(54 \pm 1.1 \mathrm{mmol} / \mathrm{mol})$ [G+MET vs NPH+MET], $p=0.93)$.

In the G+MET group the mean insulin dose was $68 \pm$ $5.7 \mathrm{U} /$ day compared with $71 \pm 6.2 \mathrm{U} /$ day in the NPH+MET group $(p=0.68)$ and the insulin dose per kilogram was $0.69 \pm 0.05 \mathrm{U} / \mathrm{kg}$ in the G+MET group compared with $0.69 \pm 0.05 \mathrm{U} / \mathrm{kg}$ in the NPH+MET group $(p=0.98)$.

\section{Circulating IGF-I bioactivity and total IGF-I at baseline}

Mean serum IGF-I bioactivity and total IGF-I did not differ between the two treatment groups at baseline (IGF-I bioactivity: $134 \pm 9$ vs $135 \pm 10 \mathrm{pmol} / \mathrm{l}$ [G+MET vs NPH+MET], $p=0.83$; and total IGF-I: $13.3 \pm 1.0$ vs $13.3 \pm 1.0 \mathrm{nmol} / 1$ $[\mathrm{G}+\mathrm{MET}$ vs NPH+MET], $p=0.97)$. 
Table 1 Baseline characteristics of diabetic patients randomised to the G+MET group or NPH+MET group within the original LANMET study and of diabetic patients (in the G+MET or NPH group) and non-diabetic participants analysed in the present study

\begin{tabular}{|c|c|c|c|c|c|c|c|}
\hline Characteristic & $\begin{array}{l}\text { LANMET study } \\
\text { G+MET }^{\text {a }}\end{array}$ & $\begin{array}{l}\text { LANMET study } \\
\text { NPH+MET }^{\mathrm{a}}\end{array}$ & $\begin{array}{l}\text { G+MET } \\
\text { group }^{b}\end{array}$ & $\begin{array}{l}\text { NPH+MET } \\
\text { group }^{b}\end{array}$ & $\begin{array}{l}\text { Non-diabetic } \\
\text { participants }\end{array}$ & $p$ value $^{\mathrm{c}}$ & $p$ value $^{\mathrm{d}}$ \\
\hline Patients $(n)$ & 61 & 49 & 57 & 47 & 41 & - & - \\
\hline Sex (male/female) & $38 / 23$ & $32 / 17$ & $35 / 22$ & $31 / 16$ & $19 / 22$ & 0.63 & 0.06 \\
\hline Age (years) ${ }^{e}$ & $56 \pm 1$ & $57 \pm 1$ & $56.0 \pm 1.2$ & $56.7 \pm 1.2$ & $56.6 \pm 1.3$ & 0.71 & 0.88 \\
\hline Metformin dose (g/day) & $2.28 \pm 0.06$ & $2.19 \pm 0.05$ & $2.16 \pm 0.05$ & $2.23 \pm 0.06$ & - & 0.38 & - \\
\hline Previous sulfonylurea (\%) & 79 & 86 & 81 & 89 & - & 0.28 & \\
\hline Previous ACE inhibitor (\%) & 57 & 55 & 53 & 49 & - & 0.84 & \\
\hline Previous beta-blocker or thiazide (\%) & 71 & 63 & 67 & 59 & - & 0.54 & \\
\hline Weight (kg) & $92.0 \pm 2.4$ & $94.4 \pm 1.2$ & $92.3 \pm 2.4$ & $95.5 \pm 2.6$ & $82.1 \pm 3.1$ & 0.36 & 0.001 \\
\hline BMI $\left(\mathrm{kg} / \mathrm{m}^{2}\right)^{\mathrm{e}}$ & $31.3 \pm 0.7$ & $32.0 \pm 0.8$ & $31.0 \pm 0.7$ & $31.9 \pm 0.8$ & $27.8 \pm 0.7$ & 0.35 & $<0.001$ \\
\hline $\mathrm{HbA}_{1 \mathrm{c}}(\%)^{\mathrm{e}}$ & $9.5 \pm 0.1$ & $9.6 \pm 0.1$ & $9.0 \pm 0.1$ & $9.2 \pm 0.2$ & $5.4 \pm 0.1$ & 0.33 & $<0.001$ \\
\hline $\mathrm{HbA}_{1 \mathrm{c}}(\mathrm{mmol} / \mathrm{mol})^{\mathrm{e}}$ & $80 \pm 1.1$ & $81 \pm 1.1$ & $75 \pm 1.1$ & $77 \pm 2.2$ & $36 \pm 1.1$ & & \\
\hline $\mathrm{FPG}(\mathrm{mmol} / \mathrm{l})^{\mathrm{a}}$ & $13.0 \pm 0.3$ & $12.9 \pm 0.3$ & $12.3 \pm 0.3$ & $11.9 \pm 0.4$ & $5.5 \pm 0.1$ & 0.43 & $<0.001$ \\
\hline C-peptide (nmol/1) & $0.98 \pm 0.04$ & $1.00 \pm 0.07$ & $1.0 \pm 0.04$ & $1.0 \pm 0.07$ & $0.7 \pm 0.06$ & 0.86 & $<0.001$ \\
\hline Serum TG $(\mathrm{mmol} / \mathrm{l})^{\mathrm{a}}$ & $2.3 \pm 0.2$ & $2.5 \pm 0.2$ & $2.0 \pm 0.2$ & $2.2 \pm 0.2$ & $1.2 \pm 0.1$ & 0.17 & $<0.001$ \\
\hline HDL-cholesterol $(\mathrm{mmol} / \mathrm{l})^{\mathrm{a}}$ & $1.18 \pm 0.04$ & $1.18 \pm 0.04$ & $1.2 \pm 0.04$ & $1.1 \pm 0.03$ & $1.5 \pm 0.07$ & 0.25 & $<0.001$ \\
\hline LDL-cholesterol $(\mathrm{mmol} / \mathrm{l})^{\mathrm{a}}$ & $2.8 \pm 0.1$ & $2.9 \pm 0.1$ & $2.7 \pm 0.1$ & $2.8 \pm 0.1$ & $3.4 \pm 0.1$ & 0.40 & $<0.001$ \\
\hline
\end{tabular}

Data are presented as mean $\pm \mathrm{SE}$

${ }^{a}$ Values from the original LANMET study; ${ }^{b}$ values from the present study

${ }^{c} p$ values are shown for differences between the G+MET group vs the NPH+MET group in the present study

${ }^{\mathrm{d}} p$ values are shown for differences between diabetic participants vs non-diabetic participants in the present study

${ }^{\mathrm{e}}$ Geometric mean

FPG, fasting plasma glucose; TG, triacylglycerol

There were also no differences in IGF-I bioactivity and total IGF-I between the two treatment groups when comparing individuals using $>70 \mathrm{U} /$ day $(118 \pm 16 \mathrm{pmol} / \mathrm{l}$ vs $129 \pm$ $14 \mathrm{pmol} / 1[\mathrm{G}+\mathrm{MET}$ vs $\mathrm{NPH}+\mathrm{MET}], p=0.67$; and $10.1 \pm$ $1.0 \mathrm{nmol} / 1$ vs $10.4 \pm 1.0 \mathrm{nmol} / 1$ [G+MET vs $\mathrm{NPH}+\mathrm{MET}$ ], $p=0.77$ ).

IGF-I bioactivity was borderline significantly lower in patients with type 2 diabetes than in non-diabetic controls (135 \pm 7 vs $161 \pm 11 \mathrm{pmol} / \mathrm{l}, p=0.09)$ (Fig. 2a). Total IGF-I concentrations were significantly lower in patients with type 2 diabetes than in non-diabetic participants $(13.3 \pm 0.7$ vs $16.3 \pm 1.0 \mathrm{nmol} / 1, p=0.03$ ) (Fig. 2b).

\section{Changes in circulating IGF-I bioactivity and total IGF-I in response to insulin therapy}

After 36 weeks of insulin treatment there were no differences in mean IGF-I bioactivity between the G+MET and the NPH + MET groups ( $116 \pm 9$ vs $117 \pm 10 \mathrm{pmol} / 1, p=0.91)$ (Fig. $2 b)$. In addition, mean total IGF-I concentrations were not different between the treatment groups $(13.4 \pm 1.0$ vs $13.1 \pm 0.9 \mathrm{nmol} / 1$ [G+MET vs NPH+MET], $p=0.71$ ) (Fig. 2b).

In addition, mean IGF-I bioactivity and total IGF-I did not differ between the G+MET and the NPH+MET groups when comparing individuals using $>70 \mathrm{U}$ insulin/day (IGF-I bioactivity: $102 \pm 15 \mathrm{pmol} / 1$ vs $114 \pm 8 \mathrm{pmol} / \mathrm{l}, p=$ 0.63 ; total IGF-I: $10.8 \pm 1.1 \mathrm{nmol} / 1$ vs $10.5 \pm 0.9 \mathrm{nmol} / 1$, $p=0.23$ ).

Mean serum IGF-I bioactivity decreased significantly from $135 \pm 7 \mathrm{pmol} / \mathrm{l}$ at baseline to $117 \pm 6 \mathrm{pmol} / 1(p=0.001)$ at 36 weeks in all patients (Fig. 2a). A significant decline in IGF-I bioactivity was also observed in individuals using $>70 \mathrm{U}$ insulin/day: $123 \pm 11 \mathrm{pmol} / \mathrm{l}$ at baseline vs $108 \pm 9 \mathrm{pmol} / \mathrm{l}$ after 36 weeks of insulin therapy $(p=0.02)$.

Serum total IGF-I concentrations remained unchanged during insulin therapy (baseline: $13.3 \pm 0.7$ vs $13.3 \pm$ $0.7 \mathrm{nmol} / 1$ after 36 weeks of insulin therapy; $p=0.86$ ) (Fig. 2b). In addition, in patients using $>70 \mathrm{U}$ insulin/day, total IGF-I did not change during treatment $(10.3 \pm 0.7 \mathrm{nmol} / 1$ at baseline vs $10.6 \pm 0.7 \mathrm{nmol} / 1$ at 36 weeks, $p=0.24$ ).

Interrelationships between insulin dose at 36 weeks, IGF-I bioactivity and total IGF-I

At 36 weeks, there was a highly significant inverse relationship between insulin dose and serum total IGF-I in both groups (total insulin dose: G+MET group, $r=-0.36, p=0.007$; $\mathrm{NPH}+\mathrm{MET}$ group, $r=-0.41, p=0.005$; insulin dose $/ \mathrm{kg}$ : 


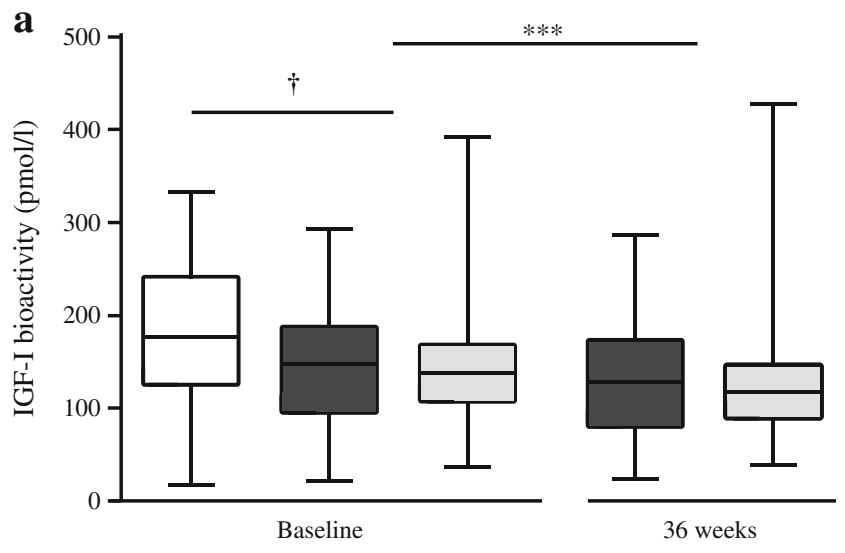

b

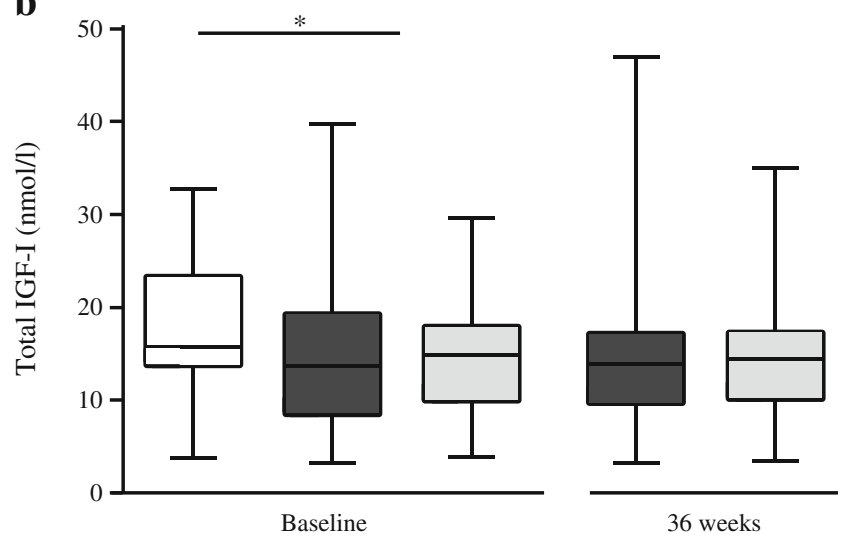

Fig. 2 a IGF-I bioactivity (pmol/l) in non-diabetic participants (white box) at baseline and in diabetic participants in the G+MET group (dark grey boxes) and in the NPH+MET group (light grey boxes) at baseline and after 36 weeks of insulin treatment. The line in the boxes represents the mean of the data. The boxes extend from the 25 th percentile to the 75th percentile values and the whiskers show the minimum and maximum values for each group. ${ }^{\dagger} p=0.09$ for IGF-I bioactivity in non-diabetic participants at baseline vs IGF-I bioactivity in diabetic patients at baseline. $* * * p<0.001$ for IGF-I bioactivity at baseline vs IGF-I bioactivity at 36 weeks in all patients. b Total IGF-I (nmol/l) in nondiabetic participants (white box) at baseline and in diabetic participants in the G+MET group (dark grey boxes) and in the NPH+MET group (light grey boxes) at baseline and after 36 weeks of insulin treatment. ${ }^{*} p=0.03$ for total IGF-I in non-diabetic participants at baseline vs total IGF-I in diabetic patients at baseline

G+MET group $r=-0.33, p=0.01 ; \mathrm{NPH}+\mathrm{MET}$ group $r=-0.36$, $p=0.02$ ), (Fig. 3). There was no significant correlation between insulin dose and IGF-I bioactivity (total insulin dose: G+MET group $r=-0.23, p=0.10$; NPH+MET group $r=-0.08, p=0.58$; insulin dose $/ \mathrm{kg}$ : G+MET group $r=-0.17, p=0.22 ; \mathrm{NPH}+\mathrm{MET}$ group $r=-0.08, p=0.58$ ), at 36 weeks.

\section{Discussion}

Insulin glargine has previously been found to be more potent than human insulin in activating the IGF-IR in vitro. However, this effect has only been observed at high (supra-physiological) insulin concentrations [6-10]. Indeed, in the present study, by using our in-house IGF-IR KIRA assay, we confirmed that at high concentrations insulin glargine is more potent than NPH insulin in activating the IGF-IR in vitro. However, in contrast to these in vitro findings, serum from type 2 diabetic patients who were treated for 36 weeks with metformin and insulin glargine induced similar IGF-IR activation compared with that of patients treated with metformin and NPH insulin for 36 weeks. Moreover, after 36 weeks of insulin treatment, IGF-I bioactivity decreased significantly in both groups. Total IGF-I concentrations were similar in both groups at baseline and remained unchanged during insulin therapy.

A sub-analysis was performed in patients who had used high mean daily insulin doses (above $70 \mathrm{U} /$ day) in order to address a previous observation of a dose-dependent increase in cancer risk for insulin glargine treatment. However, also in this sub-group, IGF-I bioactivity was similar in both groups after 36 weeks of therapy and had also decreased significantly, whereas total IGF-I remained unchanged. In addition, we found a significant inverse relationship between insulin dose and total IGF-I, but not for insulin dose and IGF-I bioactivity. Therefore, although we did not study the effects of insulin therapy on cancer incidence, our findings do not support the idea that insulin therapy raises cancer risk through an increase in IGF-I bioactivity.

In the present study insulin concentrations were not measured because of the inability of commercially available serum insulin assays to accurately measure insulin glargine. However, in a previous study, in which type 2 diabetic patients were treated with insulin glargine, a mean dose of $0.43 \mathrm{U} \mathrm{kg}^{-1}$ day $^{-1}$ resulted in mean free plasma insulin concentrations of $126 \mathrm{pmol} / 1$ [16]. In another study, the maximal concentration of serum insulin at an insulin glargine dose of $1.4 \mathrm{U} \mathrm{kg}^{-1} \mathrm{day}^{-1}$ was around $700 \mathrm{pmol} / 1$ [17]. Extrapolating these results to the maximal insulin doses that were used in our study $\left(1.7 \mathrm{U} \mathrm{kg}^{-1}\right.$ day $\left.^{-1}\right)$, it seems unlikely that free plasma insulin concentrations exceeded 500-850 pmol/1 during treatment with insulin glargine. Moreover, it has been reported that insulin glargine concentrations measured by regular insulin immunoassays are usually overestimated by $\sim 30 \%$ [18]. Taken together this suggests that in vivo concentrations of insulin glargine are unlikely to reach concentrations at which we and others have observed differences in IGF-IR activation in vitro. The latter could be an explanation of why we did not observe differences in IGF-I bioactivity between the two treatment arms. In addition, after subcutaneous injection, insulin glargine is partially degraded into two bioactive products (M1 and M2) [19]. The M1 degradation product has been shown to have less mitogenic potency than insulin glargine itself and even less potency than human insulin [6]. These findings raise the possibility that insulin glargine would be 
Fig. 3 Correlations between daily insulin dose and IGF-I bioactivity (a) and total IGF-I (b) in the G+MET (black dots) and NPH+MET (white dots) groups. a G+MET $r=-0.17$, $p=0.22$; NPH+MET $r=-0.08$, $p=0.58$. b G+MET $r=-0.33$, $p=0.01 ; \mathrm{NPH}+\mathrm{MET} r=-0.36$, $p=0.02$

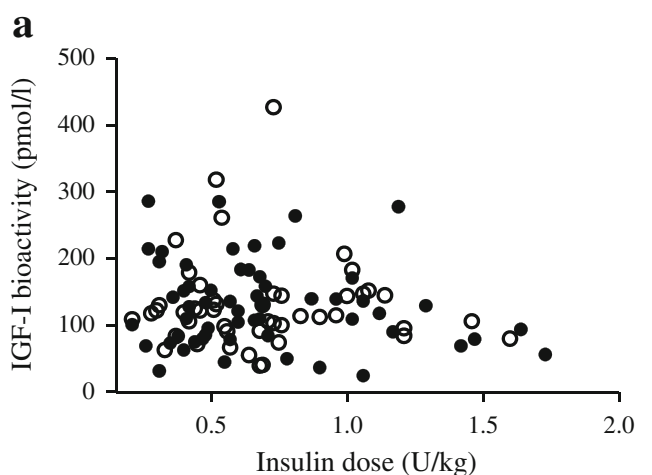

less mitogenic in vivo than it is in vitro and could be another explanation for the absence of differences in IGF-I bioactivity between the two treatment arms. Direct measurement of circulating concentrations of insulin glargine and its metabolites during insulin therapy would be helpful in clarifying this latter possibility [20].

The observed decline in IGF-I bioactivity during insulin therapy in both treatment arms is in line with a recent study, which showed that acute hyperinsulinemia suppressed IGF-I bioactivity, whereas total serum IGF-I did not change [21]. The decrease in circulating IGF-I bioactivity in the latter study was attributed to insulin-mediated effects on circulating IGF binding proteins (IGFBPs): insulin suppressed IGFBP-4 and IGFBP-1 and increased IGFBP-2 concentrations [21]. In addition, it has been reported that IGFBP-3 protease activity is increased in untreated diabetic patients and decreases after several days of insulin treatment $[22,23]$. The latter effect may also have contributed to the observed decrease in IGF-I bioactivity during insulin treatment in our study.

At baseline, IGF-I bioactivity was slightly lower in the type 2 diabetic patients than in the leaner non-diabetic participants. Although this comparison was not the primary aim of our study, this finding is in line with previous data comparing patients with type 2 diabetes with those with impaired or normal glucose tolerance [24]. One mechanism responsible for lower IGF-I bioactivity in the diabetic patients could be chronic hyperinsulinaemia (C-peptide levels were 50\% higher in the type 2 diabetic patients than in nondiabetic participants), since it has been suggested that prolonged insulin exposure inhibits $\mathrm{GH}$-induced signalling at both receptor and postreceptor level in the liver [25].

Total IGF-I concentrations were significantly lower in the diabetic patients than in the non-diabetic participants. In previous studies, total IGF-I concentrations in type 2 diabetic patients have been reported to be lower, similar to, or higher than in non-diabetic control participants [26]. Different results in these studies could be due to variability in insulin concentrations because of different treatment regimens and/or variation in insulin sensitivity in type 2 diabetes [26]. Another factor may be that in many previous studies immunoassays have been used that may not have accurately measured IGF-I levels as a result of problems with assay standardisation and/ or with assay methodology [27].

It has been suggested that the IGF-I KIRA assay is more sensitive than the commonly used total IGF-I immunoassays in detecting differences in clinical state [28]. Moreover, the IGF-I KIRA assay seems to be superior to commonly used IGF-I immunoassays in monitoring therapeutic interventions [28]. Thus the measurement of IGF-I bioactivity could be an important tool to clarify controversies that exist about the precise role of the IGF-I system in diabetes.

Our data do not support the idea that the use of insulin glargine in type 2 diabetes leads to higher circulating IGF-I bioactivity in vivo, compared with NPH insulin. Our findings are in line with a recently published paper in which, in an animal model of type 2 diabetes, no differences were demonstrated in the degree of colonic epithelial proliferation between animals treated with insulin glargine or NPH insulin [29]. Nevertheless, in that study insulin treatment did result in a higher degree of colonic epithelial proliferation, thereby pointing towards the potential mitogenic properties of all insulins, irrespective of type [29].

It is important to emphasise that, with the IGF-I KIRA, phosphorylation of the tyrosine residues within the $\beta$-subunits of the IGF-IR is quantified, but it cannot be assessed whether activation of the IGF-IR by an insulin analogue results in a normal (i.e. balanced metabolic and mitogenic) activity at cellular level in vivo. The IGF-IR may differentially elicit biological effects and intracellular signalling upon binding of different insulin analogues. In this respect it has been suggested that intracellular signalling induced by insulin analogues differs from human insulin: insulin analogues preferentially activate the extracellular signal-related kinase (ERK) pathway rather than the AKT pathway [30]. Thus there is still a chance that (subtle) differences in the molecular structure of insulin analogues may affect in vivo signalling at the postreceptor level and thereby induce an abnormal metabolic:mitogenic ratio (e.g. an increased activation of the IGF-IR may inhibit apoptosis and promote cancer by increasing cell proliferation [20]).

It should be stressed that in this study the decline in serum IGF-I bioactivity during insulin treatment was found 
under co-medication with relatively high doses of metformin. Metformin is a widely prescribed glucose-lowering drug that is recommended as the initial pharmacological therapy, together with lifestyle interventions, for type 2 diabetes [31]. All patients in our study had already been treated with metformin for at least 3 months before being randomly assigned to either insulin glargine or NPH insulin therapy. Several studies have shown that metformin treatment is associated with a lower cancer risk [4, 32, 33]. Therefore, concomitant metformin use has been suggested to be a potential confounder when it comes to estimating the risks of insulin therapy for cancer [34]. However, in our study we merely addressed IGF-I bioactivity and not cancer incidence. The potential mechanisms of a potential anticancer effect of metformin seem to be very complex [35]. Metformin reverses endogenous hyperinsulinaemia through its effects on glucose homeostasis and therefore may directly have antiproliferative effects [36]. Indirectly, a reduction of endogenous insulin levels may also lower IGF-I bioactivity by improving insulin sensitivity [37]. Most importantly, metformin activates the AMP-activated protein kinase (AMPK) signalling pathway [35]. One of the major growth regulatory pathways controlled by AMPK is the mammalian target of rapamycin (mTOR) pathway and its downstream substrates [38, 39]. In addition, in NIH-3T3 cells, stimulation of AMPK inhibits the ability of IGF-I to activate ras and its downstream targets, but phosphorylation of the activated IGF-IR appeared to be unaffected by this increase in AMPK activity [40]. Thus, metformin seems to interfere with IGF-I signalling at the postreceptor level and not at the receptor level. Nevertheless, we cannot exclude the possibility that concomitant metformin therapy has influenced our findings.

Finally, a few limitations of our study need to be addressed. First of all the LANMET study was not primarily designed and performed to study the effects of insulin therapy on IGF-I bioactivity and/or cancer incidence. We could only study IGF-I bioactivity during a relatively short follow-up period and in participants who were already treated with metformin. Therefore the post-hoc analysis in our study was inevitable. Nevertheless, again, we did not study cancer incidence. In addition, we would like to underline that, after 36 weeks of insulin treatment, there was no difference in IGF-I bioactivity between participants treated with insulin glargine or NPH insulin.

Second, as for all in vitro systems, the IGF-I KIRA bioassay does not mimic the exact in vivo conditions. Responses to insulin and insulin analogues in vivo are far more complex and are mediated by insulin receptors next to IGF-IRs and possibly also by hybrid receptors, which are widely expressed on normal tissues and often aberrantly expressed in cancer cells [41]. However, although the precise biological role of these hybrids is still unclear, functional studies have demonstrated that hybrid receptors behave more like IGF-IRs than
IRs [41] and therefore, in this context, the effects we found on IGF-IR phosphorylation could be important in vivo.

In conclusion, circulating IGF-I bioactivity was similar in poorly controlled type 2 diabetic patients who had been treated for 36 weeks with either insulin glargine or NPH insulin combined with metformin. Moreover, insulin treatment decreased IGF-I bioactivity. In addition, there was a significant inverse relationship between insulin dose and total IGF-I. Therefore, our data do not indicate increased IGF-IR signalling in type 2 diabetic patients treated with insulin glargine.

Acknowledgements The authors thank R. Kauppinen-Mäkelin (Jorvia Hospital, Espoo, Finland), M. Tiikkainen (University of Helsinki, Helsinki, Finland), H. Virtamo (City of Turku Health Centre, Turku, Finland), K. Nikkilä (Jorvi Hospital, Espoo, Finland), T. Tulokas (Lappi Central Hospital, Rovaniemi, Finland), S. Hulme (Whiston Hospital, Prescot, UK), K. Hardy (Whiston Hospital, Prescot, UK), S. McNulty (Whiston Hospital, Prescot, UK), J. Hänninen (Mikkeli Health Centre, Mikkeli, Finland), H. Levänen (Mikkeli Health Centre, Mikkeli, Finland), S. Lahdenperä (sanofiaventis, Helsinki, Finland), R. Lehtonen (sanofi-aventis, Helsinki, Finland) and L. Ryysy (Kymenlaakso Central Hospital, Kotka, Finland) for their great contribution in the LANMET study. The authors are grateful to P. Uitterlinden (Erasmus MC, Rotterdam, the Netherlands) for performing the immunoassays. Part of this study was presented as an oral presentation at the Annual Endocrine Society meeting in June 2011, Boston, USA.

Funding The LANMET study was sponsored by sanofi-aventis but the present study was investigator-initiated and not supported by grants from the industry. Sanofi-aventis had no involvement in the study design nor in the collection, analysis and interpretation of data. J.A. M.J.L. Janssen has received an unrestricted grant from Novo Nordisk A/S (Alphen aan de Rijn, the Netherlands) and sanofi-aventis (Frankfurt am Main, Germany).

Duality of interest The authors declare that there is no duality of interest associated with this manuscript.

Contribution statement AJV wrote the manuscript and researched data and edited the manuscript, JAMJLJ contributed to conception and design and reviewed/edited the manuscript, MV contributed to conception and design, contributed to the discussion and reviewed/edited the manuscript, LJH contributed to the conception and design and reviewed/edited the manuscript, SWJL contributed to conception and design, contributed to the discussion and reviewed/edited the manuscript, HY-J contributed to the conception and design, researched data and reviewed/edited the manuscript. All authors gave their final approval of this version of the manuscript to be published.

Open Access This article is distributed under the terms of the Creative Commons Attribution Noncommercial License which permits any noncommercial use, distribution, and reproduction in any medium, provided the original author(s) and source are credited.

\section{References}

1. Hemkens LG, Grouven U, Bender R et al (2009) Risk of malignancies in patients with diabetes treated with human insulin or insulin analogues: a cohort study. Diabetologia 52:1732-1744 
2. Jonasson JM, Ljung R, Talback M, Haglund B, Gudbjornsdottir S, Steineck G (2009) Insulin glargine use and short-term incidence of malignancies-a population-based follow-up study in Sweden. Diabetologia 52:1745-1754

3. Colhoun HM, SDRN Epidemiology Group (2009) Use of insulin glargine and cancer incidence in Scotland: a study from the Scottish Diabetes Research Network Epidemiology Group. Diabetologia 52:1755-1765, Erratum 52:2469

4. Currie CJ, Poole CD, Gale EA (2009) The influence of glucoselowering therapies on cancer risk in type 2 diabetes. Diabetologia 52:1766-1777

5. Food and Drug Administration (2011) FDA Drug Safety Communication: update to ongoing safety review of Lantus (insulin glargine) and possible risk of cancer. Available from www.fda.gov/Drugs/DrugSafety/ucm239376.htm, accessed 12 January 2011.

6. Kurtzhals P, Schaffer L, Sorensen A et al (2000) Correlations of receptor binding and metabolic and mitogenic potencies of insulin analogs designed for clinical use. Diabetes 49:999-1005

7. Varewijck AJ, Goudzwaard JA, Brugts MP, Lamberts SW, Hofland LJ, Janssen JA (2010) Insulin glargine is more potent in activating the human IGF-I receptor than human insulin and insulin detemir. Growth Horm IGF Res 20:427-431

8. Sciacca L, Cassarino MF, Genua M et al (2010) Insulin analogues differently activate insulin receptor isoforms and post-receptor signalling. Diabetologia 53:1743-1753

9. Eckardt K, May C, Koenen M, Eckel J (2007) IGF-1 receptor signalling determines the mitogenic potency of insulin analogues in human smooth muscle cells and fibroblasts. Diabetologia 50:2534-2543

10. Weinstein D, Simon M, Yehezkel E, Laron Z, Werner H (2009) Insulin analogues display IGF-I-like mitogenic and antiapoptotic activities in cultured cancer cells. Diabetes Metab Res Rev 25:41-49

11. Chen JW, Ledet T, Orskov H et al (2003) A highly sensitive and specific assay for determination of IGF-I bioactivity in human serum. Am J Physiol Endocrinol Metab 284:E1149-E1155

12. Brugts MP, Ranke MB, Hofland LJ et al (2008) Normal values of circulating insulin-like growth factor-I bioactivity in the healthy population: comparison with five widely used IGF-I immunoassays. J Clin Endocrinol Metab 93:2539-2545

13. Mannucci E, Monami M, Balzi D et al (2010) Doses of insulin and its analogues and cancer occurrence in insulin-treated type 2 diabetic patients. Diabetes Care 33:1997-2003

14. Mayer D, Chantelau E (2010) Treatment with insulin glargine (Lantus) increases the proliferative potency of the serum of patients with type-1 diabetes: a pilot study on MCF-7 breast cancer cells. Arch Physiol Biochem 116:73-78

15. Yki-Jarvinen H, Kauppinen-Makelin R, Tiikkainen M et al (2006) Insulin glargine or NPH combined with metformin in type 2 diabetes: the LANMET study. Diabetologia 49:442-451

16. Vehkavaara S, Yki-Jarvinen H (2004) 3.5 years of insulin therapy with insulin glargine improves in vivo endothelial function in type 2 diabetes. Arterioscler Thromb Vasc Biol 24:325-330

17. Owens DR, Bolli GB (2008) Beyond the era of NPH insulinlong-acting insulin analogs: chemistry, comparative pharmacology, and clinical application. Diabetes Technol Ther 10: 333-349

18. Westerbacka J, Bergholm R, Tiikkainen M, Yki-Jarvinen H (2004) Glargine and regular human insulin similarly acutely enhance endothelium-dependent vasodilatation in normal subjects. Arterioscler Thromb Vasc Biol 24:320-324

19. Kuerzel GU, Shukla U, Scholtz HE et al (2003) Biotransformation of insulin glargine after subcutaneous injection in healthy subjects. Curr Med Res Opin 19:34-40
20. Belfiore A, Frasca F, Pandini G, Sciacca L, Vigneri R (2009) Insulin receptor isoforms and insulin receptor/insulin-like growth factor receptor hybrids in physiology and disease. Endocr Rev 30:586-623

21. Arafat AM, Weickert MO, Frystyk J et al (2009) The role of insulin-like growth factor (IGF) binding protein-2 in the insulinmediated decrease in IGF-I bioactivity. J Clin Endocrinol Metab 94:5093-5101

22. Bereket A, Lang CH, Blethen SL, Fan J, Frost RA, Wilson TA (1995) Insulin-like growth factor binding protein-3 proteolysis in children with insulin-dependent diabetes mellitus: a possible role for insulin in the regulation of IGFBP-3 protease activity. J Clin Endocrinol Metab 80:2282-2288

23. Bang P, Brismar K, Rosenfeld RG (1994) Increased proteolysis of insulin-like growth factor-binding protein-3 (IGFBP-3) in noninsulin-dependent diabetes mellitus serum, with elevation of a 29-kilodalton $(\mathrm{kDa})$ glycosylated IGFBP-3 fragment contained in the approximately $130-$ to $150-\mathrm{kDa}$ ternary complex. J Clin Endocrinol Metab 78:1119-1127

24. Brugts MP, van Duijn CM, Hofland LJ, Witteman JC, Lamberts SW, Janssen JA (2010) IGF-I bioactivity in an elderly population: relation to insulin sensitivity, insulin levels, and the metabolic syndrome. Diabetes 59:505-508

25. Ji S, Guan R, Frank SJ, Messina JL (1999) Insulin inhibits growth hormone signaling via the growth hormone receptor/JAK2/ STAT5B pathway. J Biol Chem 274:13434-13442

26. Clauson PG, Brismar K, Hall K, Linnarsson R, Grill V (1998) Insulin-like growth factor-I and insulin-like growth factor binding protein-1 in a representative population of type 2 diabetic patients in Sweden. Scand J Clin Lab Invest 58:353-360

27. Chestnut RE, Quarmby V (2002) Evaluation of total IGF-I assay methods using samples from Type I and Type II diabetic patients. J Immunol Methods 259:11-24

28. Janssen JAMJL (2011) IGF-I: pro's and con's of a bioassay. Horm Res Paediatr 76(suppl 1):S106-S110

29. Nagel JM, Staffa J, Renner-Müller I et al (2010) Insulin glargine and NPH insulin increase to a similar degree epithelial cell proliferation and aberrant crypt foci formation in colons of diabetic mice. Horm Cancer 1:320-330

30. Vigneri R, Squatrito S, Sciacca L (2010) Insulin and its analogs: actions via insulin and IGF receptors. Acta Diabetol 47:271-278

31. Nathan DM, Buse JB, Davidson MB et al (2009) Management of hyperglycaemia in type 2 diabetes mellitus: a consensus algorithm for the initiation and adjustment of therapy. A consensus statement from the American Diabetes Association and the European Association for the Study of Diabetes. Diabetologia 52:17-30

32. Evans JM, Donnelly LA, Emslie-Smith AM, Alessi DR, Morris AD (2005) Metformin and reduced risk of cancer in diabetic patients. BMJ (Clinical Research Edition) 330:1304-1305

33. Bowker SL, Majumdar SR, Veugelers P, Johnson JA (2006) Increased cancer-related mortality for patients with type 2 diabetes who use sulfonylureas or insulin. Diabetes Care 29: $254-258$

34. Smith U, Gale EA (2009) Does diabetes therapy influence the risk of cancer? Diabetologia 52:1699-1708

35. Jalving M, Gietema JA, Lefrandt JD et al (2010) Metformin: taking away the candy for cancer? Eur J Cancer 46:2369-2380

36. Goodwin PJ, Pritchard KI, Ennis M, Clemons M, Graham M, Fantus IG (2008) Insulin-lowering effects of metformin in women with early breast cancer. Clin Breast Cancer 8:501-505

37. Pollak M (2008) Insulin and insulin-like growth factor signalling in neoplasia. Nat Rev Cancer 8:915-928

38. Shaw RJ, Bardeesy N, Manning BD et al (2004) The LKB1 tumor suppressor negatively regulates mTOR signaling. Cancer Cell 6:91-99 
39. Ning J, Clemmons DR (2010) AMP-activated protein kinase inhibits IGF-I signaling and protein synthesis in vascular smooth muscle cells via stimulation of insulin receptor substrate 1 S794 and tuberous sclerosis 2 S1345 phosphorylation. Mol Endocrinol 24:1218-1229

40. Kim J, Yoon MY, Choi SL et al (2001) Effects of stimulation of AMP-activated protein kinase on insulin-like growth factor 1- and epidermal growth factor-dependent extracellular signal-regulated kinase pathway. J Biol Chem 276:19102-19110

41. Pandini G, Frasca F, Mineo R, Sciacca L, Vigneri R, Belfiore A (2002) Insulin/insulin-like growth factor I hybrid receptors have different biological characteristics depending on the insulin receptor isoform involved. J Biol Chem 277:3968439695 